\title{
EFEKTIVITAS EKSTRAK ETANOL DAUN MAHONI (Swietenia mahagoni (L.) Jacq.) TERHADAP LARVA Aedes aegypti L.
}

\author{
Tisa Rizkika Nur Amelia' ${ }^{1)}$, Siti Sumarmi ${ }^{2}$, Tri Rini Nuringtyas ${ }^{2)}$. \\ ${ }^{1}$ Prodi Pendidikan Biologi, FKIP, Universitas Nusantara PGRI Kediri \\ ${ }^{2}$ Fakultas Biologi, Universitas Gadjah Mada \\ e-mail: ${ }^{1)}$ tisanurriskika@unpkediri.ac.id \\ ${ }^{2}$ siti-sumarmi@ugm.ac.id, tririni@ugm.ac.id
}

Diterima 3 Juni 2017 disetujui 29 Juni 2017

\begin{abstract}
The aim of the research were to evaluate the efficacy of botanical insecticide of Swietenia mahagoni leaves extracts against larvae of Aedes aegypti, based on concentration of the leaves $S$. mahagoni extract, and in additional to determine secondary metabolites compounds of S. mahagoni leaves extract. The extraction of $S$. mahagoni leaves was done by using ethanol solvents and than was analyzed by using Thin Layer Chromatography. The result indicated that ethanolic extract of S. mahagoni leaf contained alkaloid, tannin, saponin, terpenoid, and flavonoid compounds. The value of $\mathrm{LC}_{50}$ and $\mathrm{LC}_{90}$ calculation showed that $\mathrm{LC}_{50}$ of ethanolic extract over second and third instar larvae respectively were $488 \mathrm{ppm}$ and $644 \mathrm{ppm}$. However the value of $\mathrm{LC}_{90}$ of both instar larvae were $732 \mathrm{ppm}$ and $797 \mathrm{ppm}$. Based on the above result, it can be concluded that ethanolic extract of S. mahagoni leaf was effective against larvae of Ae aegypti.
\end{abstract}

Key words: Ae. aegypti, S. mahagoni, botanical insecticide

\section{PENDAHULUAN}

Demam Berdarah Dengue (DBD) merupakan penyakit yang ditularkan oleh Ae. Aegypti betina yang mengandung virus Dengue dalam tubuhnya. Virus Dengue dibedakan menjadi empat serotipa, yakni DEN-1, DEN-2, DEN-3, dan DEN-4. Empat serotipa virus tersebut berbeda, perbedaan tersebut menyebabkan individu dapat terinveksi beberapa kali (Rey, 2007). Penyakit DBD merupakan problem kesehatan di negara tropis termasuk Indonesia. Di Yogyakarta, meskipun jumlah kasus dan kematian akibat DBD telah menunjukkan penurunan, namun jumlah tersebut masih dalam kategori tinggi. Pada tahun 2011 dilaporkan jumlah kasus DBD sebanyak 985 kasus, dengan jumlah kematian sebanyak lima kasus. Tahun 2012 dilaporkan sebanyak 971 kasus dengan jumlah kematian sebanyak dua kasus. Tingginya kasus DBD di Yogyakarta tersebut tidak terlepas dari masih tingginya faktor risiko penularan, seperti angka bebas jentik yang masih di bawah 95\% (Dinas Kesehatan DIY, 2013).

Pemberantasan pada tahap larva merupakan kunci strategi program pengendalian vektor di seluruh dunia dan upaya pengendalian tersebut merupakan cara yang umum digunakan oleh masyarakat (Okumu et al., 2007). Abate adalah insektisida yang umum digunakan masyarakat Indonesia. Penggunaan abate sudah digunakan di Indonesia sejak tahun 1976 dan empat tahun kemudian yakni tahun 1980, abate ditetapkan sebagai program pemberantasan massal Ae. Aegypti di Indonesia (Daniel, 2008). Namun penggunaan abate yang termasuk insektisida kimia tersebut apabila diberikan secara terus menerus dan intensif dapat menyebabkan resistensi terhadap nyamuk Ae. Aegypti (Ocampo et al., 2011). Selain itu, insektisida kimia yang tersebar di lingkungan tidak dengan mudah terdegradasi sehingga dapat meninggalkan residu yang dapat mencemari air, tanah, 
dan udara serta menurunkan kualitas lingkungan (Felsot and Racke, 2007).

Insektisida nabati merupakan salah satu upaya untuk mengurangi pemakaian insektisida kimia yang menggunakan bahan lebih aman dan berwawasan lingkungan. Salah satu jenis tanaman yang mempunyai aktivitas insektisida adalah Swietenia mahagoni (L.) Jacq., dikenal dengan nama mahoni. Daun mahoni mengandung senyawa yang diketahui berperan aktif sebagai insektisida yakni saponin, alkaloid, tannin, flavonoid (Adhikari and Chandra, 2014), dan limonoid (Abdelgaleil et al., 2013). Selain jenis tanaman, pelarut yang digunakan dalam proses ekstraksi juga menentukan keefektivan insektisida tersebut. Hasil penelitian Amelia (2016) menunjukkan $\mathrm{LC}_{50}$ terhadap larva Ae.aegypti instar kedua dan ketiga adalah 9.756 ppm dan 17.560 ppm, sedangkan $\mathrm{LC}_{90}$ terhadap larva instar kedua dan ketiga adalah 10.899 ppm dan 18.284 ppm. Nilai tersebut masih tergolong tinggi untuk insektisida nabati, hal ini disebabkan air memiliki aktivitas ekstraksi yang sifatnya sangat polar sehingga memiliki aktivitas ekstraksi yang rendah (Tiwari et al., 2011). Hal ini dibuktikan bahwa kandungan fitokimia ekstrak air daun mahoni hanya mengandung tanin dan flavanoid (Amelia, 2016).

Oleh karena itu peneliti ingin mengganti pelarut yang sebelumnya menggunakan air dengan pelarut etanol. Pelarut etanol memiliki aktivitas ekstraksi yang tinggi karena mempunyai sifat semipolar sampai polar (Tiwari et al.,2011). Dengan demikian diharapkan ekstrak etanol daun S. mahagoni dapat secara optimal diaplikasikan sebagai insektisida nabati pengendali larva nyamuk Ae.aegypti. Tujuan penelitian ini adalah mengetahui efektivitas ekstrak etanol daun $S$. mahagoni terhadap larva instar kedua dan ketiga Ae. Aegypti dan mengetahui kandungan metabolit sekunder yang terkandung dalam ekstrak etanol daun S. mahagoni. Manfaat dari hasil penelitian ini adalah menambah informasi mengenai efektivitas ekstrak etanol daun $S$. mahagoni terhadap larva instar kedua dan ketiga Ae. Aegypti, sehingga menambah informasi insektisida nabati dari tanaman lokal daerah. Bagi pemerintah lokal daerah dan instansi terkait, informasi ini sebagai acuan untuk pengembangan lebih lanjut tanaman $S$. mahagoni dan tanaman lain yang berfungsi sebagai insektisida nabati.

\section{METODE}

\section{Waktu dan Tempat}

Penelitian dilaksanakan pada bulan September 2014-April 2015, Pembuatan ekstrak daun $S$. mahagoni dan uji efektivitas dilakukan di Laboratorium Entomologi, Fakultas Biologi UGM. Identifikasi senyawa metabolit sekunder dengan Kromatografi Lapis Tipis (KLT) dilakukan di Laboratorium Fitokimia Fakultas Farmasi UGM.

\section{Alat dan Bahan}

Alat yang digunakan meliputi timbangan semi analitik kapasitas $310 \mathrm{~g}$, gelas ukur $500 \mathrm{~mL}$, toples kaca $10 \mathrm{~L}$, gelas kimia $1000 \mathrm{~L}$, kertas lakmus, termometer, higrotermometer, serta paper cup 150 mL. Bahan-bahan yang digunakan antara lain adalah telur Ae. Aegypti yang diperoleh dari Balai Penelitian dan Pengembangan Pengendalian Penyakit Bersumber Binatang (Balai Litbang P2B2) Banjarnegara dan daun S. mahagoni berasal dari kebun mahoni di Sawitsari Research Station, Fakultas Biologi Universitas Gadjah Mada di Sawitsari, Yogyakarta, Pelarut menggunaan etanol, dan larutan Abate untuk kontrol positif.

\section{A. Prosedur Kerja}

\section{Pemeliharaan Ae. Aegypti L.}

Pemeliharaan Ae. Aegypti diadaptasi dari metode Imam et al. (2014). Telur Ae. 
Aegypti yang menempel di kertas saring ditetaskan dengan cara direndam dalam air sumur yang dimasukkan ke dalam nampan plastik dengan ketinggian air sumur $1,5 \mathrm{~cm}$. Antara satu sampai dua hari, telur akan menetas menjadi larva dan larva tersebut dipindahkan ke nampan yang berbeda yang di dalamnya terdapat air sumur, selanjutnya larva diberi pakan butiran fish food satu sendok teh. Larva yang telah menjadi pupa dipindahkan ke cup plastik volume $40 \mathrm{~mL}$ kemudian cup tersebut dimasukkan ke dalam kandang pemeliharaan nyamuk sampai menjadi dewasa. Imago Ae. Aegypti diberi larutan madu 10\% sedangkan imago betina diberi tambahan makanan yaitu darah marmut.

Pembuatan Ekstrak daun Swietenia mahagoni (L.) Jacq.

Metode ekstraksi daun S. mahagoni diadaptasi dari Kamaraj et al. (2011) dengan modifikasi. Daun dicuci dengan air mengalir, kemudian dikeringanginkan dan kemudian dihaluskan sehingga menjadi serbuk. Serbuk daun diekstraksi menggunakan pelarut etanol menggunakan teknik maserasi. Serbuk seberat 100 g ditambahkan etanol sebanyak $1 \mathrm{~L}$ dimaserasi selama 48 jam lalu disaring dengan kertas saring. Larutan ekstrak diuapkan pelarutnya hingga menghasilkan ekstrak kental dan pelarut telah menguap sempurna.

\section{Identifikasi Metabolit Sekunder}

Ekstrak Daun S. mahagoni (L.) Jacq.

Identifikasi metabolit sekunder ekstrak daun $S$. mahagoni dilakukan dengan teknik Kromatografi Lapis Tipis (KLT) yang dapat dijadikan sebagai data awal pencarian senyawa aktif sebagai insektisida nabati (Biradar dan Rachetti, 2013).

Uji Efektivitas Ekstrak Daun Swietenia mahagoni (L.) Jacq. terhadap larva instar kedua dan ketiga

Pengujian dilakukan dengan menggunakan ekstrak etanol daun $S$. mahagoni dengan kosentrasi 200, 400, 600 , dan 800 ppm, serta kontrol negatif dan kontrol positif. Larva instar kedua dan ketiga Ae. Aegypti mendapat perlakukan yang sama terhadap uji menggunakan ekstrak etanol daun S. mahagoni tersebut.

Pengujian dilakukan dengan tiga ulangan. Metode pengujian yang dilakukan terhadap larva mengacu pada metode yang dilakukan oleh WHO (2005). Larutan uji sebanyak $100 \mathrm{~mL}$ di masukkan paper cup. Pada masing-masing paper cup tersebut dimasukkan 20 larva Ae. Aegypti instar kedua dan ketiga. Pengujian ekstrak daun $S$. mahagoni menggunakan dua kontrol, yakni kontrol positif dan negatif. Kontrol positif digunakan $100 \mathrm{~mL}$ Abate $100 \mathrm{ppm}$ dan kontrol negatif digunakan larutan etanol 1\%. Kematian larva diamati setelah 24 jam.

\section{HASIL DAN PEMBAHASAN}

\section{Identifikasi Metabolit Sekunder dengan Kromatografi Lapis Tipis}

Tabel 1. Kandungan senyawa metabolit sekunder ekstrak etanol daun Swietenia mahagoni (L.) Jacq.

\begin{tabular}{lccc}
\hline \multirow{2}{*}{ Senyawa } & \multicolumn{3}{c}{ Ekstrak air } \\
\cline { 2 - 4 } & Hasil & $\begin{array}{c}\text { Jumlah } \\
\text { bercak }\end{array}$ & Rf \\
\hline Alkaloid & + & 1 & 0,5 \\
Tanin & + & 4 & 0,$13 ; 0,21 ;$ \\
Saponin & + & 1 & 0,$41 ; 0,8$ \\
Terpenoid & + & 3 & 0,49 \\
Flavonoid & + & 2 & 0,$63 ; 0,69 ; 0,79$ \\
\hline Kyyy
\end{tabular}

Keterangan: (+) mengandung senyawa; (-) tidak mengandung senyawa

Ekstrak etanol daun S. mahagoni mengandung lima senyawa yang diujikan yaitu alkaloid, tanin, saponin, terpenoid dan flavonoid. Hasil pengujian ini selaras dengan penelitian Adhikari et al. (2012) yang menunjukkan bahwa ekstrak daun $S$. mahagoni mengandung senyawa aktif yakni saponin, alkaloid, tanin, dan flavonoid. Ekstrak etanol mengandung 
senyawa metabolit yang lebih lengkap dibandingkan penelitian sebelumnya yang menggunakan ekstrak air, ekstrak air daun mahoni hanya mengandung tanin dan flavonoid (Amelia, 2016).

\section{Efektivitas ekstrak etanol daun Swietenia mahagoni (L.) Jacq.}

Hasil uji ekstrak etanol daun $S$. mahagoni dapat dilihat pada persentase rerata kematian yang tersaji pada Tabel 2 .

Tabel 2. Analisis statistik kematian larva instar kedua dan ketiga Aedes aegypti L. setelah 24 jam pemaparan ekstrak etanol daun Swietenia mahagoni (L.) Jacq.

\begin{tabular}{ccc}
\hline $\begin{array}{c}\text { Kelompok perlakuan/ } \\
\text { konsentrasi }(\mathbf{p p m})\end{array}$ & \multicolumn{2}{c}{ Rerata kematian $(\%) \pm$ standar deviasi pada stadium larva } \\
\cline { 2 - 3 } & Instar kedua & Instar ketiga \\
\hline Larutan etanol 1\% & $0,00 \pm 0,00$ & $0,00 \pm 0,00$ \\
200 & $10,00 \pm 0,00$ & $6,67 \pm 0,33$ \\
400 & $30,00 \pm 0,00$ & $21,67 \pm 0,33$ \\
600 & $63,33 \pm 0,58$ & $53,33 \pm 0,33$ \\
800 & $100 \pm 0,00$ & $95 \pm 0,58$ \\
Abate (100) & $100 \pm 0,00$ & $100 \pm 0,00$ \\
\hline
\end{tabular}

Ket. : Kelompok perlakuan menunjukkan perbedaan yang signifikan terhadap kontrol negatif dengan taraf nyata 0,05 (Chi square test)

Hasil statistik tersebut menunjukkan bahwa semua kelompok uji berbeda secara signifikan dengan kelompok kontrol negatif yaitu larutan etanol 1\% dan setiap konsentrasi yang berbeda pada kelompok uji memberikan pengaruh yang berbeda terhadap jumlah kematian larva uji. Perlakuan dengan konsentrasi 800 ppm tidak berbeda nyata dengan kontrol positif yakni larutan Abate konsentrasi 100 ppm, yang berarti senyawa kimia ekstrak daun $S$. mahagoni pada konsentrasi 800 ppm dapat menyebabkan tingkat kematian yang sama dengan Abate 100 ppm (larvasida kimia sintesis yang umum digunakan). Tingkat kematian larva setelah mendapatkan perlakuan dari ekstrak menunjukkan gambaran aktivitas larvasida yang berbeda. Persentase kematian larva Ae. Aegypti setelah pemaparan ekstrak etanol daun $S$. mahagoni menunjukkan hasil kematian yang meningkat sesuai dengan peningkatan konsentrasi ekstrak tersebut, sehingga semakin tinggi konsentrasi, maka semakin banyak jumlah kematian larva. Hal ini kemungkinan bahwa konsentrasi ekstrak daun $S$. mahagoni yang tinggi memiliki lebih banyak senyawa aktif yang bersifat toksik sehingga lebih efektif untuk membunuh larva nyamuk. Hal ini sesuai dengan hasil penelitian Widawati \& Prasetyowati (2013), Hossain et al. (2011), dan Selvaraj \& Mosses (2011).

Larva instar kedua lebih rentan terhadap ekstrak etanol daun S. mahagoni dibandingkan larva instar ketiga, hal ini dikarenakan individu yang lebih muda memiliki aktivitas makan lebih banyak dibandingkan individu yang lebih dewasa dalam hal proporsi makan dibandingkan berat tubuh (Hayes, 2011). Maka, jika makanan kedua individu diberi zat toksik, individu muda menerima dosis racun lebih tinggi dibandingkan individu yang dewasa. Selain itu, struktur anatomi kutikula serangga pada larva instar ketiga kemungkinan lebih tebal bila dibandingkan larva instar kedua.

Data hasil pengamatan kematian larva Ae. Aegypti setelah 24 jam pemaparan ekstrak etanol daun $S$. mahagoni selanjutnya dianalisis dengan uji Probit untuk menentukan $\mathrm{LC}_{50}$ dan $\mathrm{LC}_{90}$. Garis regresi probit dapat dilihat pada Gambar 1 dan hasil uji probit dapat dilihat pada Tabel 3. 

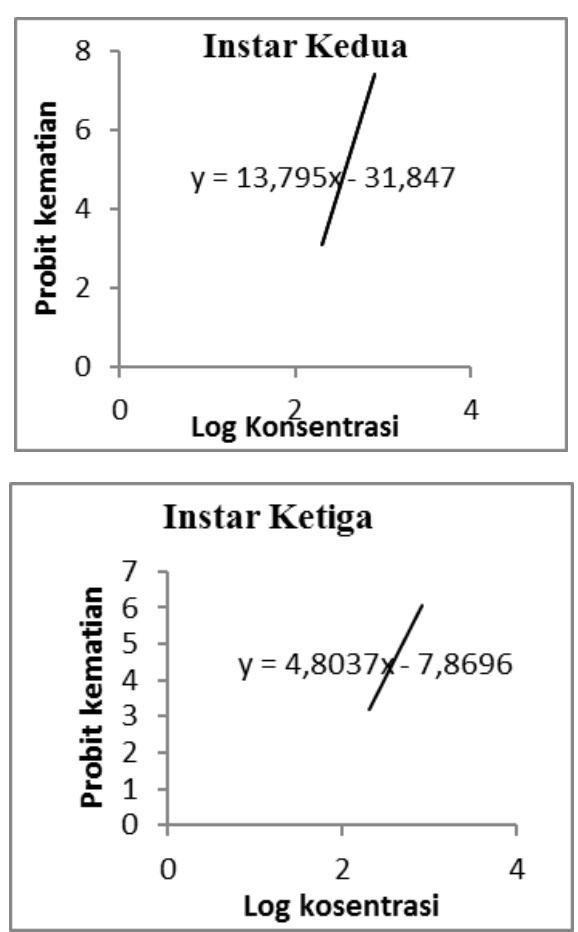

Gambar 1. Kurva persamaan regresi linier $\log$ konsentrasi ekstrak etanol daun $S$. mahagoni dengan probit kematian larva.

Tabel 3. LC50 dan LC90 ekstrak etanol daun $S$. mahagoni (L.) Jacq. terhadap larva Ae. Aegypti L.

\begin{tabular}{ccc}
\hline $\begin{array}{c}\text { Stadium } \\
\text { perkembangan }\end{array}$ & $\begin{array}{c}\text { LC50 } \\
\text { (ppm) }\end{array}$ & $\begin{array}{c}\text { LC90 } \\
\text { (ppm) }\end{array}$ \\
\hline Instar kedua & 488 & 732 \\
\hline Instar ketiga & 544 & 797 \\
\hline Hasil perhitungan & dengan & probit
\end{tabular}

analisis menunjukkan bahwa $\mathrm{LC}_{50}$ ekstrak daun mahoni terhadap larva instar dua dan tiga adalah 448 dan 544 ppm, dan $\mathrm{LC}_{90}$ ekstrak terhadap instar kedua dan ketiga adalah 732 dan 797 ppm. Nilai ini tentunya lebih rendah apabila dibandingkan dengan penelitian sebelumnya yaitu ekstrak air daun mahoni yang menunjukkan $\mathrm{LC}_{50}$ terhadap larva Ae.aegypti instar kedua dan ketiga adalah $9.756 \mathrm{ppm}$ dan $17.560 \mathrm{ppm}$ dan $\mathrm{LC}_{90}$ terhadap larva instar kedua dan ketiga adalah $10.899 \mathrm{ppm}$ dan $18.284 \mathrm{ppm}$ (Amelia, 2016). Jika nilai LC semakin rendah maka insektisida botani tersebut akan semakin efektif, sehingga ekstrak etanol daun mahoni lebih efektif dari pada ekstrak air daun mahoni. Hasil penelitian ini serupa dengan hasil penelitian beberapa peneliti yang membandingkan efektivitas ekstrak etanol dan air dari berbagai tumbuhan untuk membunuh larva nyamuk, yakni Ubulom et al. (2012) dan Nagappan (2012).

Senyawa metabolit sekunder ekstrak daun $S$. mahagoni merupakan racun perut dan racun kontak larva Ae. Aegypti. Hal ini dapat terjadi disebabkan larva yang memakan pakan yang terendam dalam larutan ekstrak, sehingga metabolit sekunder yang bersifat toksik tersebut ikut termakan oleh larva. Selain itu, senyawa toksik masuk melalui kutikula larva. Aktivitas senyawa saponin merupakan racun kontak yang akan berinteraksi dengan lipid sehingga membentuk micell yang menyebabkan rusaknya kutikula serangga (Chaieb, 2010). Alkaloid merupakan antifeedant yang menghambat kemoreseptor spesifik di alat mulut serangga bersamaan dengan gangguan fagostimulan (Mordue and Nisbet, 2000). Alkaloid juga menyebabkan kerusakan sistem syaraf pusat serangga (Reigart \& Roberts, 1999). Senyawa tanin dapat menurunkan aktivitas makan serangga (Khanna and Kannabiran, 2006). Senyawa Flavonoid dapat menurunkan aktivitas pertahanan tubuh serangga (Abu-Romman et al., 2012). Terpenoid menimbulkan efek primer terhadap serangga yakni berupa antifeedant. Selain itu, terpenoid merupakan neurotoksik yang merusak sistem syaraf serangga (Coloma et al., 2005). Ekstrak etanol konsentrasi 800 ppm dapat menyebabkan tingkat kematian larva instar kedua dan ketiga yang sama dengan kontrol positif Abate 100 ppm.

\section{SIMPULAN}

Ekstrak etanol daun S. mahagoni mempunyai $\mathrm{LC}_{50}$ terhadap larva instar dua dan tiga adalah 448 dan 544 ppm, dan $\mathrm{LC}_{90}$ ekstrak terhadap instar kedua dan ketiga adalah 732 dan 797 ppm. Ekstrak etanol daun mahoni mengandung senyawa yang dapat mematikan larva instar kedua dan 
ketiga Aedes aegypti L. Yakni alkaloid. Tanin, saponin, terpenoid, dan flavonoid. Ekstrak etanol daun mahoni efektif terhadap mortalitas larva instar kedua dan ketiga Ae. Aegypti.

\section{SARAN}

Untuk mengetahui kadar masingmasing senyawa kimia pada daun $S$. mahagoni, maka perlu dilakukan analisis senyawa daun $S$. mahagoni dengan KLT secara kuantitatif.

\section{DAFTAR PUSTAKA}

Abdelgaleil, S.A.M., Doe, M., and Nakatani, M. 2013. Rings B,DSeco Limonoid Antifeedants From Swietenia mahagoni. Phytochemistry 96 (2013) 312-317.

Abu-Romman, S., Abu-Darwish, M., \& Ghabeish, I. 2012. Impact of Flavonoids against Wolly Apple Aphid, Eriosoma lanegerum (Hausmann) and Its Sole Parasitoid, Aphelinus mali (Hald.). Journal of Agricultural Science. Vol 4 (2). doi: 10.5539/jas.v4n2p227.

Adhikari, U. \& Chandra, G. 2014. Larvacidal, Smoke Toxicity and Adult Emergence Inhibition Effects of Leaf Extracts of Swietenia mahagoni Linnaeus against Anopheles stephensi Liston (Diptera: Culicidae). Asian Pacific Journal of Tropical Disease. S279 - S283. doi: 10.1016/S2222-1808(14)60456-4.

Adhikari, U., \& Chandra, G. 2012. Laboratory Evaluation of Ethyl Acetate and Chloroform: methanol $(1: 1 \mathrm{v} / \mathrm{v})$ Extract of Swietenia mahagoni leaf against Japanese Encephalitis vector Culex vishuni Group. Asian Pacific Journal of Tropical Disease (2012)451-455.

Amelia, T.R.N. 2016. Efektivitas Ekstrak Air Daun Mahoni (Swietenia mahagoni (L.) Jacq.) terhadap Larva Aedes aegypti L. Prosiding Seminar
Nasinal IV Hayati. UN PGRI Kediri. ISBN:978-602-61371-04.

Biradar, S.R. and Rachetti, B.D. 2013. Extraction of Some Secondary Metabolites \& Thin Layer Chromatography from Different Parts of Centella asiatica L. (URB). American Journal of Life Sciences. 1 (6) : 243-247.

Chaieb, I. 2010. Saponin as Insecticides: a review. Tunisian Journal of Plant Protection. 5: 39-50.

Coloma, A.G., Guadano, A., and Tonn, C.E. 2005. Antifeedant/Insecticidal Terpenes from Asteraceae and Labiatae Species Native to Argentinean Semi-arid Lands. Naturforsch. 60 c. $855-861$

Copping, L. G. 2004. The Manual of Biocontrol Agents. Third edition of the Biopesticide Manual. BCPC Publication. UK. 250-252

Daniel.2008.Ketika Larva dan Nyamuk Dewasa Sudah Kebal Terhadap Insektisida. FARMACIA. Vol.7 No.7.

Dinas Kesehatan Daerah Istimewa Yogyakarta. 2013. Profil Kesehatan Daerah Istimewa Yogyakarta. pp. 234-245. (http://dinkes.jogjaprov. go.id/files/64370-Profil-KesDIY-2012.pdf). Diakses April 2014.

Felsot, A.S. and Racke, K.D. 2007. Chemical Pest Control Technology : Benefits, Disadvantages, and Continuing Roles in Crop Production System. American Chemical Society : Washington DC. pp. $4-6$.

Hayes, W.J.(Ed). 2011. Hayes' Handbook of Pesticide Toxicology. Third edition. Vol 1 \& 2. Elsivier Inc. Pp 53-88.

Hossain, E., Rawani, A., Chandra, G., Mandal, S.C., \& Gupta, J.K. 2011. Larvacidal Activity of Dregea volubilis and Bombax malabaricum Leaf Extracts againts the Filarial Vector Culex quinquefasciatus. Asian Pasific Journal of The 
Medicine. 436-441.

Imam, H., Zarnigar, Sofi, G., and Aziz, S. 2014. The Basic Rules and Mathods of Mosquito Rearing (Aedes aegypti). Dispatches. 4 (1) 53-55.

Kamaraj C., A. Bagavan, G. Elango, A.A. Zahir, G. Rajakumar, S. Marimuthu, T. Santhoshkumar \& A.A. Rahuman. 2011. Larvicidal Activity of Medicinal Plant Extracts Against Anopheles subpictus \& Culex tritaeniorhynchus. Indian $J$ Med Res 134, pp 101-106

Khanna, V.G. \& Kannabiran, K. 2006. Larvicidal Effect of Hemidesmus indicus, Gymnema sylvestre, and Eclipta prostrata against Culex quinquifasciatus Mosquito larvae. African Journal of Biotechnology. Vol. 6 (3), pp $307-311$.

Lardo, S. 2013. Penatalaksanaan Demam Berdarah Dengue dengan Penyulit. CDK-208/ vol. 40 no. 9. (http:// www.kalbemed.com) Diakses April 2014.

Mordue, A.J. \& Nisbet, A.J. 2010. Azadirachtin from the Neem Tree Azadirachta indica: its Action Against Insects. An Soc. Entomol. Brasil 29 (4): 615-632.

Nagappan, R. 2012. Evaluation of Aqueous and Ethanol Extract of Bioactive Medicinal Plant, Cassia didymobotrya (Fresenius) Irwin \& Barneby Against Immature Stages of Filarial Vector, Culex quinquefasciatus Say (Diptera: Culicidae). Asian Pacific Journal of Tropical Biomedicine; 2(9): 707-71. doi:10.1016/S2221-1691(12)602147

Nugroho, A.D. 2011. Kematian Larva Aedes aegypti setelah Pemberian Abate Dibandingkan dengan Pemberian Serbuk Serai. Jurnal Kesehatan Masyarakat. 7(1): 91-96.

Ocampo, C.B., Salazar-Terreros, M.J., Mina, N.J. 2011. Insecticide resistance status of Aedes aegypti in 10 localities in Colombia. Acta Tropica. 118 (2011) 37-44.

Okumu FO, Knols BGJ and Fillinger U.2007. Larvacidal Effect of a Neem (Azadirachta indica) oil formulation on the malaria vector Anophleles gambiae. Malaria Journal.6 (63).

Reigart, J.R. \& Roberts, J.R. 1999. Recognition and Management of Pesticide Poisonings (5th). Washington, DC. pp 63-73

Rey, J. 2007. What is Dengue? Entomology and Nematology Department, Florida Cooperative Extension Service. Institute of Food and Agricultural Sciences. University of Florida. (http://edis.ifas.ufl.edu/ IN699). Diakses April 2014.

Selvaraj, M. \& Mosses, M. 2011. Efficacy of Melia azedarach on the Larvae of Three Mosquito species Anopheles stephensi, Culex quinquefasciatus, and Aedes aegypti (Diptera: Culicidae). Journal of the Europan Mosquito Control Association. 29, 116-121.

Tiwari, P., Kumar, B., Kaur, M., Kaur, G., \& Kaur, H. 2011. Phytochemical Screening and Extraction: A review. International Pharmaceutica Sciencia. Vol 1. Issue 1.

Ubulom, P. M. E., Imandeh, G. N., Ettebong, E. O. \& Udobi, C. E. 2012. Potential larvicidal properties of Blighia sapida leaf extracts against larvae of $\mathrm{An}$. gambiae, $\mathrm{Cu}$. quinquefasciatus and Ae. Aegypti. British Journal of Pharmaceutical Research 2 (4): 259-268

Walker, K. 2002. A Review Of Control Methods for African Malaria Vectors. Environmental Health Project. Washington DC : US. pp. 5-7.

WHO. 2005. Guidelines for Laboratory and Field Testing of Mosquito Larvicides. WHO/CDS/WHOPES/ 
GCDPP/2005.13. World Health Organization, Geneva, Switzerland. pp. 5-14.

Widawati, M \& H. Prasetyowati. 2013. Efektivitas ekstrak buah Beta vulgaris L. (buah bit) dengan berbagai fraksi pelarut terhadap mortalitas larva Aedes aegypti. Aspirator.5(1): 23-29. 